\title{
The Temporal Trend Analysis of Extreme Rainfall Events in Ga-West District of Accra, Ghana
}

\author{
Samuel Amutty \\ Institute for Environment and Sanitation Studies, University of Ghana. Box LG 209, Legon, Accra
}

\begin{abstract}
The research was self-financed.
\end{abstract}
\section{Abstract}

The increasing frequency and impacts of flooding in the world have been blamed on global warming and climate change together with other anthropogenic factors. However some studies maintain the recent increase in flooding globally is mainly due to increasing extreme precipitation or rainfalls. In Ghana also, some researchers, technocrats and ordinary people believe that the recent increase in flooding in the city of Accra is resulting from increasing occurrence of extreme rainfall events, attributed to climate change. But this view was contested by other researchers who attributed the increasing flooding events purely to anthropogenic factors. This study, therefore, analyzed the temporal trend of extreme rainfall events from 1970 to 2009 to ascertain whether extreme rainfall events have been increasing significantly over the period under review in Ga West District to warrant the increasing flood events in the study area. A Manual Mann-Kendall Statistical Trend Test Table was used to analyze extreme 24hour maximum rainfall events which were extracted from secondary rainfall data procured from Ghana Meteorological Agency(GMet) for the Airport Weather Station as proxy data. Since the major raining season occurs from April to July in southern Ghana, the annual number of days of these extreme 24 hour maximum rainfall events for the four months were extracted from the raw data for each year, from 1970 to 2009 for temporal trend analysis at the $\mathrm{p}=0.05$ level of significance. The hypothesis of the study was as follows: i) Null hypothesis ( $\left.\mathrm{H}_{0}\right)$ : there was no monotonic trend in the extreme 24-hour maximum rainfall events in the study area. ii) Alternative hypothesis $\left(\mathrm{H}_{1}\right)$ : there was a monotonic trend in the extreme 24 hour maximum rainfall events in the study area. The study found that $Z=0.0058$ which was less than $Z(1-\mathrm{p} / 2)=1.96$ at $p=0.05$ significant level. The null hypothesis $\left(\mathrm{H}_{0}\right)$ was, therefore accepted and the alternative hypothesis rejected. The acceptance of the null hypothesis shows that there was no statistically significant increase in extreme 24 hour maximum rainfall events in the study area. The study, therefore, concluded that since there was no statistically significant increasing trend in extreme 24 hour maximum rainfall events, extreme rainfall events could not be the reason for the increasing flooding in the study area as some believed, but rather anthropogenic factors, or a combination of both.

Keywords: Mann-Kendal statistical trend test, extreme 24hour maximum rainfall, anthropogenic factors, climate change, temporal analysis

DOI: $10.7176 / \mathrm{JEES} / 10-12-05$

Publication date: December $31^{\text {st }} 2020$

\section{Introduction}

Flood disasters are considered the most destructive of all natural disasters in terms of deaths, health hazards and damages to properties (Miller, 1997). The frequency and extent of these flood disasters globally, and the accompanying losses and related human health impacts, are expected to increase over the next 50 to 100 years (Stern, 2007). To make matters worse, fast rate of urbanization taking place worldwide is making more people and assets exposed to flood risks especially in the cities around the world (IPCC 2001). Though global warming and climate change and other anthropogenic factors(IPCC 2001; Evans et al. 2004) have been jointly pointed as the reasons for the devastating flooding phenomenon worldwide, some studies blamed the increasing flood events globally mainly on the increasing occurrence of extreme precipitation (rainfall) events, attributed to climate change. An extreme rainfall event was defined by a Ghana Meteorological Agency official as a heavy rainfall event beyond the treshold of $64 \mathrm{~mm}$. Though many previous studies have attributed the increasing flooding activities in Accra mainly to anthropogenic factors, recent views being expressed by various categories of people including some researchers blamed the increasing flooding in the city on the increasing occurrence of extreme rainfall events, making opinion on the issue mixed. Therefore, conducting a temporal trend analysis of extreme rainfall events in the study area is important to ascertain whether there had been any significant increase in extreme rainfall events to warrant increase in flooding over the period.

Though some researchers attributed the recent increasing factors to various factors, other researchers (McEwen, 1989; Schecham and Hewitt 1969; Smith, 1996; Oriola, 1994 ; Babatolu, 1996) blamed increased occurrence of extreme precipitation (rainfall) events, attributed to climate change, as the major cause of recent increasing flood disasters worldwide. Some climatic models also predicted that there would be increase in precipitation (rainfall) in some areas, especially monsoonal regions, along with changes in the frequency and intensity of extreme rainfall events (Handmer al., 1999; Arnell et al., 2001; Cubasch et al., 200). Other predictions also indicated that flooding would increase in both developed and developing countries, as a result of increasing 
heavy rainfall (Madsen \& Figdo, 2007). These model predictions have brought about public debate about the apparent increased frequency of extreme rainfall, and more particularly, about perceived increases in rainfall intensities (Dyson, 2000). These have led to several scientific studies on trends and seasonality of extreme rainfall events worldwide.

Some of these scientific studies on trends confirmed that extreme rainfall events are already increasing in countries like USA and Australia (Easterling et al. 2000, Haylock and Nicholls 2000, Groisman et al. 2001; Kunkel 2003), Western New Zealand (Salinger and Griffiths 2001); United Kingdom in winter (Osborn et al. 2000), and South Africa (Fauchereau et al., 2003). However, the outcomes of some studies in Canada showed no trend at all in the occurrence of extreme rainfall or precipitation events (Zhang et al. 2001; Kunkel, 2003). Yet in other studies in Western Australia (Haylock and Nicholls, 2000); South-East Asia and parts of central Pacific (Griffiths et al. 2003); Northern and Eastern New Zealand (Salinger and Griffiths, 2001) and United Kingdom in summer (Osborn et al, 2000) it was obvious that there were significantly decreasing trends in extreme rainfall events.

In Ghana, Greater Accra Metropolitan Area (GAMA), an urban conglomerate also called Accra (Brinkhoff, 2010), is one of the flood endemic city. Various studies show that the flood disasters recorded in the city of Accra over the years were mainly attributed to various anthropogenic factors such as poor physical planning and flaws in the drainage network; massive growth of the city, preventing infiltration by impervious surfaces; informal housing development practices and poor waste management practices in the city which are indicators of rapid and unplanned urbanization (Karley 2009; Aryeetey-Attoh , 2001; Arnold et al., 1996; Yeboah 2000, 2003; Afeku 2005). But some other studies (Gyau-Boakye,1998; Opoku-Ankomah,1996; Kwaku \& Duke 2007; Douglas et al., 2008; Odai, 2009; Simister, 2010) also mentioned extreme rainfall events as a key cause of flood disasters in GAMA. Hence anthropogenic factors and heavy rainfall have been jointly blamed for the increasing frequency of flooding in the Accra by previous researchers.

However, recent opinion being expressed in local media discourse by both ordinary people and technocrats seemed to favour the view that increasing occurrence of extreme rainfall events, attributed to climate change, were mainly responsible for the increasing devastating floods in GAMA. This opinion was somehow corroborated by Environmental Protection Agency (EPA) of Ghana in a study on climate change in Ghana, when they reported that 'climate change is leading to more intensive rainfall events which caused flood events on 23rd April, 2008 and 24th June, 2009 in parts of Accra that wreaked havoc on life and properties' (Kankam-Yeboah et al.(2010). This view was also supported by Douglas et al. (2008) who pointed to the possible role of climate change in the form of increased rainstorm frequency and intensity contributing to the increasing flood disasters in GAMA. But the researchers indicated that the severity of the flood disasters was exacerbated by local factors. Furthermore, rainfall figures collected from GMet between 1961 to 2010 also seemed to support the above opinion by indicating that rainfall events have gradually increased over the 1986-1995 period, including a high number of 24-hour maximum rainfall events, a trend said to have continued in the last decade (Tschakert et al. 2010).

Ga West District is one of the districts where flood activities have increased with severe impacts. Though the flood prone communities in the district are relatively new flood prone corridors according to NADMO (2008), they have suffered extremely from series of flood disasters and the frequency of the flood activities were said to be increasing. In 2007 for instance, the losses suffered by the victims in these flood prone communities during the June flood were described as quite catastrophic leading to the death of five (5) people in the study area (Ghanaian Times, 2007). When views of residents of the flood prone communities were randomly sampled, during an informal reconnaissance survey on the main cause of the frequent flooding activities in the area, there was a wide spread belief in the area that increasing extreme rainfall events, attributed to climate change, was mainly responsible for the recent increasing flood activities in the study area. However, contrary to the view above, Karley (2009), in a study on flooding and urban planning in Accra concluded that heavy rainfall events and increased intensity of rainfall may result in flooding but the recent increasing flood disasters in Accra were not resulting from increasing extreme rainfalls attributed to climate change.

From the foregoing, it is obvious that opinions on whether climate change was leading to increased extreme rainfall events in Accra, and for that matter, Ga West District or not, was contested and mixed. Yet, little or no academic research existed in the local literature that effectively analyzed temporal trend of extreme rainfall events to settle this controversy. An earlier study by Karley(2009) which analyzed temporal rainfall trend, used seasonal mean rainfall in Accra and concluded that there was no significant increasing trend. But it was argued that this was because the contributions from increasing heavy rainfall events were offset by decreasing moderate rainfall events and so hid a lot of information. Moreover, Karley used regression analysis (a parametric method) which is only powerful in detecting trend in independent and normally distributed data but not in a non-normally distributed data as in rainfall data. The most common non-parametric test for working trend in this kind of time series is the Mann-Kendall (Mann, 1945; Kendall, 1975). There was, therefore, paucity of information about the temporal trend of extreme rainfall in Ga West District in the local literature, a gap this study intended to fill.

The purpose of this study, therefore, was to analyze the temporal trend of extreme rainfall events in Ga West District to ascertain whether any significant increase had occurred over the years. The hypothesis of the study, 
therefore, was: i) The null hypothesis $\left(\mathrm{H}_{0}\right)$ : there was no trend in the extreme 24-hour maximum rainfall in the study area. ii) The alternative hypothesis $\left(\mathrm{H}_{1}\right)$ : there was a significant monotonic trend in the extreme 24 hour maximum rainfall events in the study area.

The result of this study would establish whether or not climate change is actually leading to increase in extreme rainfall events claimed to be contributing to increasing flood activities in the study area. This would help bring an end to the debate on whether climate change, through extreme rainfall events, is responsible for the increasing flooding activities in the study area or not.

\subsection{Materials and Method}

\subsection{Study Area}

Ga West District was chosen as the study area through informal conversation with some key Officials of National Disaster Management Organization (NADMO) of Ghana, based on the fact that it is one of the relatively recent areas in GAMA that was suffering from flood disasters. Four communities in the district (Malam, Santa Maria, Kwashibu and Awoshie) were then chosen based on their constant vulnerability to flood hazards in the district according to the records of NADMO.

Ga West District is part of an urban agglomeration, often referred to as the Greater Accra Metropolitan Area (GAMA). It basically corresponds to the areas covered by the Accra Metropolitan assembly (AMA), the Ga East District Assembly (GEDA), the Ga West District Assembly (GWDA) and the Tema Municipal Assembly (TMA) (SWITCH Accra, 2009) which is coterminous with Accra (Brinkhoff, 2010).

The District is located in the Greater Accra region of Ghana. It is the second largest of the six Districts in Greater Accra Region. It lies within latitude 5'048"north, 5'029'North and longitude 008' West and 0'030"west, and shares common boundaries with Ga East and Accra Metropolitan Assembly to the East, Akwapem South, Suhum Kraboa Coalter and West Akim to the North, Awutu Efutu Senya to the West, and the Gulf of Guinea to the South. It carries a land area of approximately 710.2sq km (Ga West District Assembly, 2004). The land area consists of gentle slopes interspersed with plains in most parts and generally undulating at less than $76 \mathrm{~m}$ above sea levels. (Ga West District Assembly, 2004)

Lafa is one of the seven natural drainage system found in GAMA. The Lafa drain is a very extensive drain with numerous seasonal tributaries. It stretches from Sowutuom/Chantan and drains parts of Kwashiebu, Santa Maria, Anyaa, Awoshie, Gbawe, Mallam and parts of Dansoman and finally joins the sea around Panbros area. The Lafa is not lined at the moment and most portion of the Lafa drain is found in Ga West District (Watertech, 2004). Figure 2.1 and 2.2 below shows the the map of Ga West District and Lafa drainage basin.

\subsection{Rainfall Data Collection:}

A secondary data of raw 24-hour maximum rainfall events (Daily rainfall events) was procured from Ghana Meteorological Agency (GMet), specifically from the Kotoka International Airport Synoptic Weather Station (KIASWS) as a proxy data for the period 1970 to 2009 for temporal analysis. The proxy data was collected from KIASWS instead of Weija Weather Station, which is closer to the study area, for the following reasons: i) The Weija Weather Station and KIASWS fall in the same climatic zone.

ii) KIASWS, which is at the south eastern side of the study area, is only about $10 \mathrm{~km}$ away from the study area and so can be assumed to be the same point station according to WMO (1973) and "Glossary of Meteorology" (Huschke, 1959) which variously classified point station as having an area in the order of $1000 \mathrm{~km} 2$ and station with areas less than $550 \mathrm{~km}(<550 \mathrm{~km})$ respectively. iii) Unlike the Weija Weather Station, the data needed for this analysis was about $90 \%$ available at KIASWS.

Since most of the rainfall events in Ga West District of Greater Accra Region, occur in the major rainy season (April, May, June and July) in Southern Ghana, the rainfall data used was limited to this period. So annual number of days of extreme 24hour maximum rainfall events in the months of April to July (major raining season) was then extracted from the raw daily rainfall data for each year, from 1970 to 2009, for temporal trend analysis. Extreme 24 hour maximum rainfall in this work is defined as a daily rainfall event with a threshold above $64 \mathrm{~mm}$ according to key official of GMet.

\subsection{Data Analysis}

Mann-Kendall Statistical Trend Test is a ranked based approach that consists of comparing each value of the time series with the remaining in a sequential order. The non-parametric Mann-Kendall test is commonly employed to detect whether monotonic trends exist in time series of environmental data, climate data or hydrological data such as temperature, rainfall and stream flow (Yue \& Wang, 2004; Mavromatis \& Stathis, 2011). There are two advantages of using this test. First, it is a non-parametric test and does not require the data to be normally distributed. Second, the test has low sensitivity to abrupt breaks due to inhomogeneous time series (Tabari et al., 2011). Any data reported as non-detects are included by assigning them a common value that is smaller than the smallest measured value in the data set (Mann 1945; Kendall 1975). According to the test, the null hypothesis $\left(\mathrm{H}_{0}\right)$ 
is that there is no trend in the population from which the dataset is drawn. The alternative hypothesis $\left(\mathrm{H}_{1}\right)$ on the other hand is that there is a monotonic trend in the dataset.

So this non-parametric Mann- Kendall trend test was applied to extreme 24hour maximum rainfall events extracted from rainfall data collected from GMet on KIASWS to investigate the temporal trend of extreme 24hour maximum rainfall events in the study area. In order to make correct statistical decisions, the test statistics was evaluated at the $(\mathrm{p}=0.05)$ level of significance. The computational procedure for the Mann Kendall test considers the time series of $n$ data points and $\mathrm{Xi}$ and $\mathrm{Xj}$ as two subsets of data where $\mathrm{i}=1,2,3, \ldots, n-1$ and $\mathrm{j}=\mathrm{i}+1, \mathrm{i}+2, \mathrm{i}+3, \ldots$, $\mathrm{n}$. The data values are evaluated as an ordered time series. Each data value is compared to all subsequent data values. The initial value of the Mann-Kendall statistic, $\mathrm{S}$, is assumed to be 0 (e.g., no trend). If a data value from a later time period is higher than a data value from an earlier time period, $\mathrm{S}$ is incremented by 1 . On the other hand, if the data value from a later time period is lower than a data value sampled earlier, $\mathrm{S}$ is decremented by 1 . For instance, the data (sampling event 1) is sequentially compared to sampling events 2 through $\mathrm{n}$, then (sampling event 2) is also compared to sampling events 3 through $n$, and so on. This procedure fills each row with a $+1,0$ or -1 , based on the first rules below. The net result of all such increments and decrements yields the final value of $\mathrm{S}$ (Drapela \& Drapelova, 2011).

The Mann-Kendall S Statistic is computed as follows:

$$
S=\sum_{i=1}^{n-1} \sum_{j=i+1}^{n} \operatorname{Sign}\left(X_{j-} X_{i}\right)
$$

$\operatorname{Sign}\left(X_{j}-X_{i}\right)\left\{\begin{array}{r}1 \text { if } X_{j-} X_{i}>0 \\ 0 \text { if } X_{j-} X_{i}=0 \\ -1 \text { if } X_{j-} X_{i}<0\end{array}\right\}$

Where $X_{j}$ and $X_{i}$ are the annual values in years $j$ and $i, j>i$, respectively.

If $\mathrm{n}<10$, the value of $|\mathrm{S}|$ is compared directly to the theoretical distribution of $\mathrm{S}$ derived by Mann and Kendall. The two tailed test is used. At certain probability level $\mathrm{H}_{0}$ is rejected in favor of $\mathrm{H}_{1}$ if the absolute value of $\mathrm{S}$ equals or exceeds a specified value $S \alpha / 2$ where $S \alpha / 2$ is the smallest $S$ which has the probability less than $\alpha / 2$ to appear in case of no trend. A positive (negative) value of $\mathrm{S}$ indicates an upward (downward) trend (Drapela \& Drapelova, 2011).

For $\mathrm{n} \geq 10$, the statistic $\mathrm{S}$ is approximately normally distributed with the mean and variance as follows:

Mean $\rightarrow \mathrm{E}(\mathrm{S})=0$

The Variance (Var) for the S-statistic is defined by:

$\operatorname{Var}(S)=\frac{1}{8}\left[\mathrm{n}(\mathrm{n}-2)(2 \mathrm{n}+5)-\sum_{\mathrm{p}=1}^{\mathrm{g}} \mathrm{t}_{\mathrm{p}}\left(\mathrm{t}_{\mathrm{p}}-1\right)\left(2 \mathrm{t}_{\mathrm{p}}+5\right)\right] \rightarrow$

where $\mathrm{n}$ is the number of data points, $\mathrm{g}$ is the number of tied groups (a tied group is a set of sample data having the same value), and $t_{p}$ is the number of data points in the $\mathrm{p}^{\text {th }}$ group. For instance, in the sequence $\{2,3$, non-detect, 3 , non-detect, 3 , we have $\mathrm{n}=6, \mathrm{~g}=2, \mathrm{t}_{\mathbf{1}}=2$ for the non-detects, and $\mathrm{t}_{\mathbf{2}}=3$ for the tied value 3 .

The formulae for standardized test statistic $\mathrm{Z}$ is given by:

$$
\left\{\begin{array}{c}
Z=\frac{S-1}{[\operatorname{Var}(S)]^{\frac{1}{2}}}, \quad \text { if } S>0 \\
Z=0, \quad \text { if } S=0 \\
Z=\frac{S+1}{[\operatorname{Var}(S)]^{\frac{1}{2}}}, \quad \text { if } S<0
\end{array}\right\}
$$

A positive value of $\mathrm{Z}$ indicates an increasing trend in the time- series, while a negative $\mathrm{Z}$ value indicates decreasing trend. To test for either increasing or decreasing monotonic trend at $p$ significant level, the null hypothesis $\mathrm{H}_{0}$, is rejected if the absolute value of $\mathrm{Z}$ is greater than $\mathrm{Z}(1-\mathrm{p} / \mathbf{2})$, where $\mathrm{Z}(1-\mathrm{p} / \mathbf{2})$ is obtained from the standard normal cumulative distribution tables and represents the standard normal deviates and $\mathrm{p}$ is the significant level for the test. This means the alternate hypothesis is accepted indicating a statistically significant trend exists in the time series (Motiee \& McBean, 2009).

\subsection{Presentation of Results}

Using the formula (i) below, a Manual Mann-Kendall statistic table was constructed with 1, 0 and -1 distributed along the row according the rules below. The table was derived by comparing the first data point (sampling event 1) sequentially to sampling events 2 through $n$ which is the total data points, then second data point(sampling event 2 ) is also compared to sampling events 3 through $n$, and so on. 
$S=\sum_{i=1}^{n-1} \sum_{j=i+1}^{n} \operatorname{Sign}\left(X_{j-} X_{i}\right)$

$$
\left\{\begin{array}{r}
1 \text { if } X_{j-} X_{i}>0 \\
0 \text { if } X_{j-} X_{i}=0 \\
-1 \text { if } X_{j-} X_{i}<0
\end{array}\right\}
$$

So $+1,-1$ or 0 on each row of the manual Mann-Kendall statistic table 3.1 below was summed up and the results of the various rows were further added to obtain the Mann-Kendall Statistic (S). Hence, Mann-Kendall test statistics $(\mathrm{S})$ from the table below was calculated as follows:

$\mathrm{S}=26+(-1)+(-22)+(-22)+(-3)+(-3)+(21)+(-2)+(-2)+(-2)+(18)+(-1)+(17)+(17)+(1)+(1)+(15)+$ $(-9)+(14)+(14)+(-15)+(2)+(12)+(12)+(-5)+(-5)+(-10)+(9)+(-5)+(8)+(-4)+(-6)+(-6)+(-1)+(-$ $1)+(-1)+(2)+(0)$

Hence the Mann-Kendall test statistics(S) $=43$

Next, the variance of S, $\operatorname{Var}(\mathrm{S})$, was calculated using formula (2) below, which for the purposes of clarity and ease, was broken down into Var1 and Var2 and later put together to get $\operatorname{Var}(\mathrm{S})$.

$\operatorname{VAR}(S)=\frac{1}{8}\left[\mathrm{n}(\mathrm{n}-2)(2 \mathrm{n}+5)-\sum_{\mathrm{p}=1}^{\mathrm{g}} \mathrm{t}_{\mathrm{p}}\left(\mathrm{t}_{\mathrm{p}}-1\right)\left(2 \mathrm{t}_{\mathrm{p}}+5\right)\right]$
So $\operatorname{Var}_{1}=[n(n-2)(2 n+5)]$ and $\operatorname{Var}_{2}=\left[\sum_{\mathrm{p}=1}^{\mathrm{g}} \mathrm{t}_{\mathrm{p}}\left(\mathrm{t}_{\mathrm{p}}-1\right)\left(2 \mathrm{t}_{\mathrm{p}}+5\right)\right]$

Hence, $\operatorname{VAR}(\mathrm{S})=\frac{1}{8}\left[\operatorname{Var}_{1}-\operatorname{Var}_{2}\right]$. In this study, $\mathrm{n}=40, \mathrm{~g}=4, \mathrm{t}_{1}=4$ for tied value $3, \mathrm{t}_{2}=7$ for tie value $2, \mathrm{t}_{3}=13$ for tie value 0 and $t_{4}=15$ for tie value 1 .

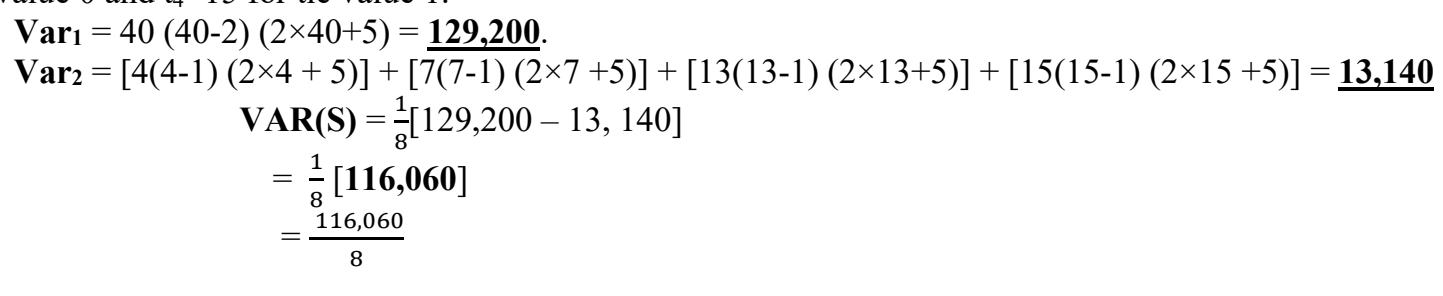

$$
\operatorname{VAR}(\mathrm{S}) \approx \underline{\mathbf{1 4 5 0 8}}
$$

Since $S>0$, the normalized test statistic $(Z)$ was calculated using the following formula:

$$
\begin{aligned}
Z=\frac{S-1}{[\operatorname{Var}(S)]^{\frac{1}{2}}} & \\
\text { Hence, } \mathbf{Z} & =\frac{43-1}{\sqrt{14,508}} \\
& =\frac{42}{7254}
\end{aligned}
$$

\section{$\mathrm{Z} \approx \mathbf{0 . 0 0 5 8}$}

With the chosen significant level, $\mathrm{p}=0.05$, the standard normal deviate is derived as follows: $\mathrm{Z}(1-\mathrm{p} / 2)=\mathrm{Z}\left(1-\mathrm{D}^{0.05} / 2\right)=\mathrm{Z}(1-0.025)=\mathrm{Z}(0.975)$. From the standard normal table, $\mathrm{Z}(0.975)=1.96$.

Hence $Z(1-\mathrm{p} / 2)=1.96$ at 0.05 significant level

\subsection{Discussions}

The study analyzed the temporal trend of extreme 24hour maximum rainfall events in Ga West District from 1970 to 2009 at $\mathrm{p}=0.05$ significant level to ascertain whether any significant increase had occurred in the period under review to warrant any increase in flooding in the study area. The hypothesis of the study, therefore, was: i) The null hypothesis $\left(\mathrm{H}_{0}\right)$ : there was no trend in the extreme 24-hour maximum rainfall in the study area. ii) The alternative hypothesis $\left(\mathrm{H}_{1}\right)$ : there was a significant monotonic trend in the extreme 24hour maximum rainfall events in the study area. The research findings would help clear the confusion in the mind of people as to the main culprit of the increasing flood disasters in the study area and help appropriate authorities and policy makers to concentrate their efforts on developing policies and programmes for dealing with the actual causes increasing flood disasters in the study area.

Since the study found the standardized normal test statistics, $Z$, to be equal to $\mathbf{0 . 0 0 5 8}$ and the positive value of the $\mathrm{Z}(\mathbf{0 . 0 0 5 8})$ is less than $\mathrm{Z}(1-\mathrm{p} / 2)=1.96$ at $\mathrm{p}=0.05$ significant level, it shows that the null hypothesis $\left(\mathrm{H}_{0}\right)$ was accepted and the alternative hypothesis $\left(\mathrm{H}_{1}\right)$ was rejected. The acceptance of the null hypothesis $\left(\mathrm{H}_{0}\right)$ meant that when the time series (extreme 24 hour maximum rainfall events) was analyzed at $p=0.05$ significant level, no monotonic trend was found. However, acceptance of the hypothesis $\left(\mathrm{H}_{0}\right)$ did not mean that there was no trend at all. Motiee \& McBean (2009), indicated that a positive value of $\mathrm{Z}$, shows that there is an upward trend in a time 
series. Hence the positive value of $\mathrm{Z}$ in this study indicated that there was an upwards trend of extreme 24hour maximum rainfall events in the study area. However, the evidence was not sufficient enough under the chosen significant level $(\mathrm{p}=0.05)$ to conclude that a significant trend exists. This means that though there was an upward trend in the extreme 24 hour maximum rainfall between 1970 and 2009, the increase was not statistically significant enough to warrant the increase in flood disasters said to be occurring in the study area.

The result of this study supports the research conducted by Karley (2009) in the city of Accra which found no trend in rainfall events, even though Karley used regression analysis and seasonal rainfall for the analysis which was considered unsuitable for such studies. It also reinforces other studies conducted in Canada which found no trend in the occurrence of extreme precipitation (rainfall) (Zhang et al. 2001; Kunkel, 2003).

The finding of this study, however, contradicts the finding of EPA research (Kankam-Yeboah et al., 2010) conducted in Accra which indicated that climate change was leading to more intensive rainfall events causing flood disasters. In addition, it also deviates from the finding of numerous studies that showed significant increasing trend of extreme precipitation (rainfall) in some parts of the world like USA and Australia (Easterling et al. 2000, Haylock and Nicholls 2000, Groisman et al. 2001; Kunkel 2003), and significant decreasing trends in extreme rainfall events in other parts of the world like Western Australia ( Haylock and Nicholls, 2000), South-East Asia and parts of central Pacific (Griffiths et al. 2003).

Hence, the finding of the study does not support the widely held perception among residents in the flood prone areas of Ga West District that the increasing flood disasters in the area was resulting from increased extreme rainfall events attributed to the climate change, neither did it support the views of some technocrats and ordinary people in the media to the effect that increasing extreme rainfall events, resulting from climate change, were responsible for the recent increasing flood disasters in the city of Accra.

The implication of this study is that though climate change might be significantly influencing temperatures and sea level rise in GAMA, there was no sufficient evidence that it significantly increased extreme rainfall events over the period under review, to warrant the increasing flood activities in the study area. What this meant was that any increasing frequency in flood disasters in the study area could not be a result of increasing extreme rainfall events. Hence, the increasing flooding phenomenon reported in Accra and for that matter the study area, could be mainly attributed to anthropogenic factors such as: rapid urbanization, improper land use practices, inadequate provision of drains, choked drains, and haphazard development in low lying areas and garbage deposition in drainage channels as mentioned by other researchers, or a combination of anthropogenic factors and extreme rainfall events. It also implies that though climate change is acknowledged as happening globally, it impacts on extreme rainfall events vary from one region to another region.

One potential limitation of this study was the use of proxy data from KIASWS instead of Weija Weather Station which is closest to the study area but lacked the desired data for the period under review. Though both weather stations fall within the diameter of the same point station, the result might be slightly affected.

\subsection{Conclusion}

The study analyzed the role of extreme rainfall events in the recent increasing damaging flooding in Ga West District in Ghana. The study was conducted against the backdrop of controversy that increasing occurrence of extreme precipitation (rainfall), attributed to climate change, was the major cause of the increasing flood disasters in Accra and for that matter in flood prone communities of Ga West District.

From the foregoing analysis, it became obvious that though there was upward trend in the extreme 24-hour maximum rainfall events, the rise was not statistically significant at $\mathrm{p}=0.05$ significant level and so cannot be responsible for the increasing flood activities being experienced in the Ga West District of Accra. Climate change, therefore, was not producing any statistically significant increase in extreme rainfall events capable of increasing flooding in the study area.

In effect, even though increase in flooding has been attributed to the occurrence of extreme precipitation (rainfall) in some parts of the world such as USA and Australia, Western New Zealand; United Kingdom in winter and South Africa, the same cannot be said about some areas in the world including Ga West District of Accra. This is because the opinion that climate change is leading to increase in extreme rainfall events blamed for increased flood activities in Ga West District was not supported by the finding of this research. Hence the increase in flood activities in the study area can best be explained by anthropogenic factors or a combination of both extreme rainfall events and anthropogenic factors.

\section{References}

Afeku. K. (2005). Urbanization and Flooding in Accra, Ghana [unpublished Master's thesis]. Submitted to the Department of Geography. Oxford : Miami University.

Arnell, N., Liu, C., Compagnucci, R., da Cunha, L., Hanaki, K., Howe, C., Mailu, G., Shiklomanov, I. \& Stakhiv, E. (2001). Hydrology and Water Resources. [Online] http://www.cuahsi.org/cyberseminars/DeWalle20041028-paper.pdf (Accessed 20/12/09) 
Arnold, J., Chester, L., \& Gibbons, C. (1996). Impervious surface coverage: the emergence of a key environmental indicator. [Online] Journal of the America Planning Association. 62(2). pp. 243-258. Available from: doi:10.1080/01944369608975688 (Accessed 10/21/20)

Aryeetey-Attoh, S., (2001). Urban Planning and Management under Structural Adjustment. In: KonaduAgyemang K, editor. IMF and World Bank sponsored structural adjustment programs in Africa. Burlington (VT): Ashgate.

Babatola, J. (1996). Recent Changes in Rainfall Patterns and its Implication for Flood Occurrence in Ondo, Nigeria. Ondo. Journal of Arts and Social Sciences, 1 (1), pp. 125 - 136.

Brinkhoff, T. (2010). City Population.[Online] Available from: http://www.citypopulation.de (Accessed 12/8/10)

Cubasch, U., Meehl, G.., Boer, G.., Stouffer, R.., Dix, M., Noda, A.., Senior, C., Raper, S. \& Yap, K. (2001). Projections of Future Climate Change. In IPCC (Houghton, J., Ding, Y., Griggs,D., Noguer, M., van der Linden, P., Dai, X.,Maskell, K. \& Johnson, C.(Eds), Climate change (2001) the scientific basis. Cambridge: Cambridge University Press

Douglas, I., Alam, K., Maghenda, M., Mcdonnell, Y., Mclean, L., Campbell, J. (2008)‘Unjust waters: climate change, flooding and the urban poor in Africa'. Environment and Urbanization. 20(1):187-205

Drapela, K. \& Drapelova, I. (2011). Application of Mann-Kendall test and the Sen's slope estimates for trend detection in deposition data from Bílý Kř́̌́z (Beskydy Mts., the Czech Republic) 1997-2010. Beskdy. 4 (2), pp. 133-146.

Easterling, D., Meehl, C., Parmesan, S., Changnon, T., Karl, L. \& Mearns, L. (2000). Climate extremes: Observations, modeling, and impacts. Science. 289(5487), pp. 2068-2074.

Evans, E., Ashley, R., Hall, J., Penning-Rowsell E., Saul, A., Sayers, P., Thorne, C. \& Watkinson, A. (2004). Foresight Flood and Coastal Defence (two volumes). London: Office of Science and Technology,

Faucherean, N., Trzasku, S., Roualt, M. \& Richard, Y. (2003). Rainfall variability and changes in the southern Africa during twentieth century in the global warming context Natural Hazards, 29 (2), pp. 139-154

Ga West District Assembly (2004). Ga West District Assembly Brochure. Accra: GWDA

Global Facility for Disaster Reduction and Recovery[GFDRR] and Climate Investment Funds (2011). Ghana Country Program for Disaster Risk Management and Climate Adaptation. Accra: World Bank/ GFDRR and UNDP.

Griffiths, M., Salinger, M, Leleu I. (2003). Trends in extreme daily rainfall across the south Pacific and relationship to the South Pacific convergence zone. International Journal of climatology. 23(8), pp. 847-869

Groisman, P., Knight, R. \& Karl, T. (2001). Heavy precipitation and high stream flow in the contiguous United States : Trends in the twentieth century. Bulletin of the American Meteorological Society, 82(2), pp. 219 246.

Gyau-Boakye, P. (1997). Flood Control Measures: Hazard Mapping. Accra: Water Research Institute of Centre for Scientific and Industrial Research (CSIR).

Handmer, J. (2000). Are Flood Warnings Futile? Risk Communication in Emergencies. Australasian Journal of Disaster and Trauma Studies, .2(2000), pp. 14

Haylock, M. R. \& Nicholls, N. (2000). Trends in extreme rainfall indices for an updated high quality data set for Australia 1910 - 1998'. International Journal of Climatology, 20(13), pp.1533-1541

Huschke, R.. (1959). Glossary of Meteorology, Boston, Massachusetts: American. Meteorological Society

IFRC (2003). World Disasters Report. [Online] Geneva: International Federation of Red Cross and Red Crescent Societies. Available from: http://www.ifrc.org/publicat/wdr2003/ (Accessed 23/02/09)

Intergovernmental Panel on Climate Change (McCarthy, J., Canziani. O., Leary, N., Dokken, D., White. K. (eds)) (2001). Climate Change 2001: Impacts, Adaptation, and Vulnerability. Cambridge: Cambridge University Press.

Kankam-Yeboah, K., Misigo, B. \& Obuobi, E. (2010). Climate change impacts on water resources in Ghana.[Online] Accra: CSIR Water Research Institute

Available from: http://www.natcomreport.com/ghana/livre/climate-change.pdf (Accessed 23/12/10)

Karley. N. (2009). Flooding and physical planning in urban areas in West Africa: situational analysis of Accra, Ghana. Theoretical and Empirical Researches in Urban Managemen,t, 4(13), pp. 25-41

Kendall, M. (1975). Rank Correlation Methods. London: Charles Griffin

Kunkel, K. (2003). North American trends in extreme precipitation. Natural Hazards, 29(2):291-305

Kwaku, S. Duke, O. (2007). Characterization and analysis of one day annual maximum and two to five consecutive days' maximum rainfall of Accra, Ghana. ARPN Journal of Engineering and Applied Sciences 2(5), pp.2731

Madsen,T. \& Figdo, E. (2007). When it rains, It Pours. Global warming and the rising frequency of extreme precipitation in the United States, American Research and Policy Centre

Mann, H. (1945). Non-parametric tests against trend. Econometrica 13(3), pp 245-259

Mavromatis T., Stathis D., (2011). Response of the Water Balance in Greece to Temperature and Precipitation 
Trends. Theoretical and Applied Climatology,[Online] ,104(1) pp.13-24.Available from:.104:13-24, DOI 10.1007/s00704-010-0320-9.[Accessed 22/08/11]

McEwen, L. (1989). Extreme Rainfall and its Implication for Flood Frequency: A Case Study of the Middle River Tweed Basin, Scotland. Transactions of the Institute of British Geographers, 14( 3). pp. 287 - 298.

Miller ,J. (1997). Floods: People at Risk, Strategies for Prevention. New York: United Nations-Department of Humanitarian Affairs.

Motiee, H., \& McBean E., (2009). An Assessment of Long Term Trends in Hydrologic Components and Implications for Water Levels in Lake Superior. Hydrology Research, 40(6), pp.564-579.

National Disaster Management Organization [NADMO] (2009). Summary of disaster events in Ghana. NADMO .[Online] Available from: http:// www.nadmo.gov.gh [Accessed 23/12/09]

Odai, S. (2009). Preserving the hydrology of urban Ghana through implementing integrated water resources management. In: Feyen, J., Shannon, K., Neville, M., (editors). Water and urban development paradigms. London: Taylor \& Francis Group.

Oriola, E. (1994). Strategies for combating urban flooding in a developing nation: A case study of Ondo, Niger. The Environmentalist, 14(1), pp. 57-62

Osborn, T., Hulme, M., Jones, P., Basnett, T. (2000). Observed trends in the daily intensity of United Kingdom precipitation. International Journal of Climatology. 20(4), pp.347-364

Opoku-Ankomah, Y. (1996) Rainfall Pattern in Accra. Accra: WRI,

Rain, D., Engstrom, R., Ludlow. C., Antos, S. (2011). Accra Ghana: a city vulnerable to flooding and drought induced migration: case study prepared for cities and climate change. Global report on human settlements 2011.[Online] Available from: http://www.unhabitat.org/grhs/2011 [Accessed 12/12/11]

Salinger, M. \& Griffiths., M. (2001). Trends in New Zealand daily temperature and rainfall extremes. International Journal of Climatology, 21(12), pp. 1437-1452

Simister, R. (2010). Urban water management: using the city water balance model to model urban water systems in Accra, Ghana [unpublished Master's thesis]. Submitted to the School of Earth Sciences. Birmingham: University of Birmingham

Schecham, L. \& Hewitt, K. (1969). A Pilot Survey of Global Natural Disasters of the Past Twenty Years. Natural Hazard Research Working Paper No. 11, Department of Geography, University of Toronto.

Smith, K. (1996). Environmental hazards: Assessing risk and reducing disaster. London: Routledge

Stern, N. (2007). The economics of climate change: the Stern review

SWITCH Accra (2009). Analysis of Water Resources Infrastructure, Demand and Access to Uurban water services in Accra.[Online] Available from: http://switchurbanwater.lboro.ac.uk/cities/1.php (Accessed 20/04/10)

Tabari, H., Marofi, S., Aeini, A., Talaee, P.H., Mohammadi, K. (2011). Trend Analysis of Reference Evapotranspiration in the Western half of Iran. Agricultural and Forest Meteorology, 151(2), pp. 128-136

Tschakert, T., Sagoe, R., Ofori-Darko, G., Codjoe, N. (2010). Floods in the Sahel: An analysis of anomalies, memory, and anticipatory learning. Climatic Change, 103(3), pp. 471-502.

$\mathrm{http}: / /$ ieeexplore.ieee.org/xpl/freeabs all.jsp?arnumber=1026807 [12/08/09]

Twumasi, Y.\& Asomani-Boateng, R. (2002). Mapping Seasonal Hazards for Flood Management in Accra, Ghana Using GIS. Proceedings of the IEEE International Geoscience and Remote Sensing Symposium (IGARSS) Conference, Westin Harbour Castle, Toronto, 24-28 June 2002.[Online] Available from: $\mathrm{http}$ ://ieeexplore.ieee.org/xpl/freeabs_all.jsp?arnumber=1026807 [Accessed 23/05/ 09]

Watertech Ltd (2004). Accra storm Drainage Improvement Works. Preliminary Design Report. Accra: Accra Metropolitan Assembly

World Meteorological Organization[WMO](1973). Manual for Estimation of Probable Maximum Precipitation (WMO)No.332).Geneva: Secretariat of the World Meteorological Organization

Yeboah, I. (2000). Structural adjustment and emerging urban form in Accra, Ghana. Africa Today. Africa Today 47(2), pp. 60-89

Yeboah, I. (2003). Demographic and housing aspects of structural adjustment and emerging urban form in Accra, Ghana. Africa Today, 50(1):107-119

Yue, S.\& Wang, C. (2004). The Mann-Kendall Test Modified by Effective Sample Size to Detect Trend in Serially Correlated Hydrological Series. Water Resources Management, 18(18), pp. 201-218.

Zhang, X., Hogg, W. \& Mekis, F. (2001). Spatial and temporal characteristics of heavy precipitation events over Canada. Journal of Climate, 14(9), pp.1923-1936

Mr Amutty Samuel Kormla was a former Student of Institute for Environment and Sanitation Studies, University of Ghana, Legon, who works with Ghana Education Service Accra. He is currently a Social Studies teacher at Uman Bun Hatab Junior High School and a researcher. The author was born in a small town in the Volta Region of Ghana called Tsibu Awudome on the 6th of June, 1972. He entered University of Ghana, Legon, Accra, in 2002 and obtained his Bachelor of Art degree in Geography and Resource Development in 2006. He later in 2007 
enrolled for a master's programme at Institute for Environment and Sanitation Studies, University of Ghana, and obtained his MPhil in Environmental Science in 2011. He has some research experience in Ghana in the area of environmental hazard and climate change. His key teaching interest areas are: environmental hazard, climate change, waste management, Geographic information systems, Environmental Law and Policy, Environmental Management etc.

\section{Appendix}

Table 3.1: Manual Mann-Kendall Statistic Table

\begin{tabular}{|c|c|c|c|c|c|c|c|c|c|c|c|c|c|c|c|c|c|c|c|c|c|c|c|c|c|c|c|c|c|c|c|}
\hline $\begin{array}{ll} & 1 \\
\text { s } & \\
x & \end{array}$ & $\begin{array}{l}1 \\
3 \\
3 \\
\text { d } \\
1 \\
1\end{array}$ & $\begin{array}{l}3 \\
3 \\
3\end{array}$ & \begin{tabular}{|l|} 
\\
9 \\
4 \\
4
\end{tabular} & 격 & $\begin{array}{l}\begin{array}{l}1 \\
9 \\
7 \\
8\end{array} \\
\end{array}$ & 영 & 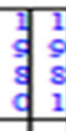 & $\begin{array}{ll}1 & 1 \\
9 & 9 \\
9 & \\
1 & \\
\end{array}$ & $\begin{array}{l}\text { 경 } \\
\text { 夏 } \\
\end{array}$ & $\begin{array}{l}1 \\
9 \\
9 \\
4\end{array}$ & $\begin{array}{l}\text { मs } \\
\text { s } \\
\text { s }\end{array}$ & $\begin{array}{l}1 \\
9 \\
8 \\
7 \\
\end{array}$ & $\begin{array}{l}\text { 경 } \\
\text { g } \\
\text { g }\end{array}$ & & & $\begin{array}{l}1 \\
9 \\
9 \\
9 \\
9 \\
2 \\
2\end{array}$ & $\begin{array}{l}\text { ㄱ } \\
\text { S } \\
3 \\
\end{array}$ & & $\begin{array}{l}1 \\
9 \\
9 \\
5\end{array}$ & & & & $\begin{array}{l}2 \\
9 \\
9\end{array}$ & & & $\begin{array}{l}2 \\
0 \\
0 \\
3\end{array}$ & & & 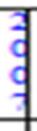 & & \\
\hline & & & $d_{1}$ & 1] & $d_{1}$ & 1 & 1 & $d_{1}$ & $d$ & $d$ & & $d$ & d & $d$ & & 31 & $d$ & & 2 & 2 & & & d & & & 3 & & & & 1 & \\
\hline & 7 & & & 7. & 97 & 7 & 70 & 97 & 9 & 9 & & 9 & 7 & वे & 9 & 7 & 9 & & 7 & 7 & 8 & & 9 & & & 7 & & & 9 & 7 & 1 \\
\hline & & & 40 & 9 & 70 & 9 & $9=$ & $=99$ & & 7 & 90 & -1 & 7 & 7 & 7 & 79 & 7 & & 7 & 7 & & & 7 & & & 7 & & q & 7 & व & \\
\hline & & & & 7 & & - & & & & -7 & & & वै & -7 & & f- & - & & d & वे & & & & & & & & & & & \\
\hline & & & 1 & 1 & 1 & 1 & 1] & 1 & 1 & 1] & 1 & 1 & 1 & 1 & 1 & 11 & 1 & & & & & 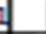 & 1 & & & 1 & & 1 & 1 & 1 & 1 \\
\hline & & & 7 & & $7 \overline{7}$ & 7 & 7 & 7 & 7 & - & & $\overline{1}$ & 9 & 7 & & 7 & 7 & & 9 & 9 & & C & j & & & 7 & & & 7 & 7 & 才 \\
\hline & & & & & & & $9=$ & 9 & & 1 & & & & 7 & & नीवे & 7 & & 7 & & & & 1 & & & & & 9 & 7 & c & \\
\hline & & & & & 9 & 9 & & 9 & & -1 & व & 7 & 7 & 7 & & 70 & 7 & & 7 & & & & - & & & 7 & & 9 & 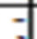 & 0 & 4 \\
\hline & & & & & & & 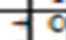 & $\frac{1}{d}$ & & d & & $\frac{1}{d}$ & & वै & & 7 & वै & & 4 & & & & $\frac{1}{d}$ & & & $\frac{1}{4}$ & & & वै & & \\
\hline & & & & & & -1 & & 1 & & - & 구 & - & 1 & & & 11 & & & 1 & 1 & & & & & & 1 & & 1 & & & \\
\hline & & & & & & 9 & $\overline{1}$ & q & & $\overline{1}$ & 9 & $\overline{1}$ & & $\overline{1}$ & & 19 & 1] & & 1 & & & & $\overline{1}$ & & & & & & 7 & 9 & 4 \\
\hline & & & & & & & & 9 & & & व & & 7 & 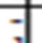 & 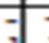 & 79 & 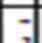 & & 7 & & & & $\overline{7}$ & & & 7 & & c & 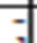 & 9 & \\
\hline & & & & & & & & q & & - & व & - & & & & व & & & & & & & & & & & & C & 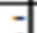 & & \\
\hline & & & & & & & 1 & 1] & 1 & 1 & & 1 & 1 & 긴 & 1 & & 고 & & 1 & -1 & & 1 & 1 & 1 & 1 & 1 & & & 1 & & 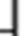 \\
\hline & & & & & & & & & & 9 & & 9 & 1 & 9 & & 1 & 9 & & 1 & & & & c & & 1 & 1 & & & 9 & 1 & 1 \\
\hline & & & & & & & & & & 7 & व & - & & - & & $=0$ & - & & 7 & & & & - & & & & & q & - & व & 9 \\
\hline & & & & & & & & & & & & & & & & & a & & & & & & 0 & & & & & & 1 & & \\
\hline & & & & & & & & & & 4 & & 4 & 1 & 4 & & $1]$ & 4 & & 1 & & & & 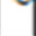 & 1 & & 1 & & 1 & 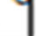 & 1 & 7) \\
\hline & & & & & & & & & & & & 9 & 7 & 9 & & 7 & q & & 7 & & & & 0 & & 7 & ] & & & q & 3 & ר \\
\hline & & & & & & & & & & & c & - & & - & - & 70 & $=$ & & 7 & & & & $=$ & & 7 & - & & c & $=$ & a & q \\
\hline & & & & & & & & & & & & & & & & & & & & & & & -1 & & & & & & & 0 & 4 \\
\hline & & & & & & & & & & & & 1 & 1 & 1 & ] & & & & 1 & & & & 1 & & & 1 & & & 1 & & \\
\hline & & & & & & & & & & & & & 7 & & 9 & t. & 9 & & 1 & 7 & & 1 & 9 & 1 & & 1 & & 1 & 9 & $\overrightarrow{1}$ & 7 \\
\hline & & & & & & & & & & & & & & & & & & & वे & & & & & & & & & & & & \\
\hline & & & & & & & & & & & & & & & 1 & 1 & & & 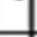 & & & & 1 & 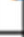 & & 1 & & 1 & 1 & 1 & \\
\hline & & & & & & & & & & & & & & & & 1 & & & & & & & & & & & & & & 1 & \\
\hline
\end{tabular}

